\section{Contraception for women taking antiepileptic drugs}

I read with interest the review by O'Brien and Guillebaud on contraception for women taking antiepileptic drugs. ${ }^{1}$ The authors are to be commended for their comprehensive review of the pharmacological literature. I note, however, that there is no reference to the most relevant publication from the Faculty of Sexual and Reproductive Healthcare (FSRH) on antiepileptic drugs, ${ }^{2}$ and there is little mention of Faculty guidance on drug interactions, ${ }^{3}$ nor any indication of where the authors' recommendations differ from those of the FSRH. Of the FSRH publications that are included, two have been archived $^{4}{ }^{5}$ and were superseded by more recent statements ${ }^{2}{ }^{6}$ before the article submission date. This is likely to add confusion to what is already a complicated subject.

I also question whether such personal views on clinical management would have been more appropriately expressed in a commentary than a review article. The Faculty's Clinical Effectiveness Unit (CEU) recognises the need for pragmatic and common sense advice in this area of medicine where robust evidence is often lacking and the consequences of contraceptive failure are serious. Indeed, some of O'Brien and Guillebaud's suggestions are likely to be incorporated into the latest update of Faculty guidance on Drug Interactions with Hormonal Contraception due to be published in January 2011. ${ }^{7}$ I would like to emphasise, however, that the following practices are not currently recommended by the CEU:

- Use of two desogestrel (Cerazette ${ }^{\circledR}$ ) tablets daily in women taking enzyme-inducing drugs

- Use of two ulipristal acetate $\left(\mathrm{ellaOne}^{\circledR}\right)$ tablets in women taking enzymeinducing drugs

- Addition of a daily oral desogestrel tablet in users of the progestogen-only implant(Implanon ${ }^{\circledR} /$ Nexplanon $^{\circledR}$ )who are taking enzyme-inducing drugs

- Use of two desogestrel (Cerazette) tablets daily in women taking lamotrigine.
Louise Melvin, MRCOG, MFSRH

Director, FSRH Clinical Effectiveness Unit; Consultant, Sexual \& Reproductive Health, Sandyford, Glasgow, UK; Louise.melvin@nhs.net

Competing interests None.

J Fam Plann Reprod Health Care 2011;37:60. doi:10.1136/jprhc.2010.0026

\section{REFERENCES}

O'Brien MD, Guillebaud J. Contraception for women taking antiepileptic drugs. J Fam Plann Reprod Health Care 2010;36:239-242.

2 Faculty of Sexual \& Reproductive Healthcare Clinical Effectiveness Unit. Faculty Statement from the CEU. Antiepileptic Drugs and Contraception. 2010. http://www. fsrh.org/admin/uploads/CEUStatementADC0110. pdf [accessed 29 October 2010].

3 Faculty of Family Planning and Reproductive Health Care Clinical Effectiveness Unit. FFPRHC Guidance (April 2005). Drug interactions with hormonal contraception. J Fam Plann Reprod Health Care 2005;31:139-150. http://www.fsrh.org/admin/ uploads/DruglnteractionsFinal.pdf [accessed 29 October 2010].

4 Faculty of Family Planning and Reproductive Health Care Clinical Effectiveness Unit. FFPRHC Guidance (July 2005). The use of contraception outside the terms of the product licence. J Fam Plann Reprod Health Care 2005;31:225-242. http:// www.fsrh.org/admin/uploads/archive/ ContraceptionProductLicence.pdf [accessed 29 October 2010].

5 Faculty of Family Planning and Reproductive Health Care. Faculty Statement from the CEU on Changes to Prescribing Information for Lamotrigine. 2005. http://www.fsrh.org/admin/uploads/archive/ lamotrigine05.pdf [accessed 29 October 2010]

6 Faculty of Sexual and Reproductive Healthcare. Statement from the FSRH Clinical Standards Committee, the Clinica Effectiveness Committee and the Associate Members' Working Group on the Prescription, Administration or Supply of Contraceptive Medicines for Use Outside the Terms of Their Licences. 2009. http://www.fsrh.org/admin/ uploads/JointStatementOffLabelPrescribing.pdf [accessed 29 October 2010].

7 Faculty of Sexual \& Reproductive Healthcare Clinical Effectiveness Unit.

FRSH Guidance (January 2011). Drug Interactions with Hormonal Contraception (in press). 